\title{
GENETIC DIVERSITY AMONG AND WITHIN BRAVE BEAN (Capparis flexuosa L.) POPULATIONS ASSESSED USING RAPD MARKERS ${ }^{1}$
}

\author{
JORGE XAVIER DE ALMEIDA NETO ${ }^{2 *}$, MAILSON MONTEIRO DO RÊGO ${ }^{3}$, ELIZANILDA \\ RAMALHO DO REGG ${ }^{4}$, ANA PAULA GOMES DA SILVA ${ }^{5}$
}

\begin{abstract}
Brave bean (Capparis flexuosa L.) is a Caatinga species that is used as forage, mainly during the dry season when some plant species lose their leaves. The aim of this study was to assess genetic diversity within and among brave bean populations using Random Amplified Polymorphic DNA (RAPD) markers. Brave bean leaves were collected from 30 accessions in the following municipalities of Paraíba state, Brazil: Barra de Santa Rosa (BSR), Cuité (C), São João do Cariri (SJC), Damião (D), Baraúna (B), and Picuí (P). DNA extraction followed the standard methodology of CTAB with modifications. RAPD analyses were carried out using 18 primers, and polymorphism of the amplified DNA fragments was visualized using agarose gel electrophoresis. Data were used to calculate Jaccard Similarity Coefficient values, which were then used to group samples with the Unweighted Pair Group Method with Arithmetic Mean. Cophenetic Correlation Coefficient, Stress, and Distortion Coefficient values were also calculated from these analyses. Band polymorphism was generated with 14 primers, but the sampled populations showed low numbers of polymorphic loci (27 in BSR, 18 in $\mathrm{C}, 7$ in SJC, 9 in $\mathrm{D}$, and 0 in $\mathrm{B}$ and $\mathrm{P}$ ). The highest polymorphic information content was found in samples from the BSR (9 groups), C (22 groups), SJC (7 groups), and D (6 groups) municipalities. In the interpopulation analysis, 34 groups were formed, the matrices of which showed high cophenetic correlations (0.95 to 0.98$)$, but low stress (12.9 to $17.45 \%)$ and distortion (3.05\%). Therefore, results showed that there was genetic variability both among and within brave bean populations.
\end{abstract}

Keywords: Biotechnology. Caatinga. Molecular marker. Species conservation.

\section{DIVERSIDADE GENÉTICA ENTRE E DENTRO DE POPULAÇÕES DE FEIJÃO-BRAVO (Capparis flexuosa L.) USANDO MARCADORES RAPD}

RESUMO - O feijão-bravo (Capparis flexuosa) é uma espécie nativa da Caatinga e é utilizada como forrageira, principalmente na estação seca onde parte das espécies vegetais perdem suas folhas. Objetivou-se estudar a diversidade genética dentro e entre populações de feijão-bravo usando marcadores RAPD. O estudo foi realizado no Laboratório de Biotecnologia Vegetal do CCA/UFPB. Foram coletadas folhas de 30 acessos de feijão-bravo/população nos seguintes municípios do estado da Paraíba: Barra de Santa Rosa (BSR), Cuité (C), São João do Cariri (SJC), Damião (D), Baraúna (B) e Picuí (P). A extração de DNA seguiu a metodologia de utilização do $\mathrm{CTAB}$ com modificações. Análises de RAPD foram realizadas usando 18 primers e o polimorfismo de fragmentos de DNA amplificados foi visualizado em gel de agarose após eletroforese. Os dados foram submetidos ao Coeficiente de Similaridade Jaccard, agrupados seguindo a UPGMA e calculou-se o Coeficiente de Correlação Cofenética, Estresse e Distorção. 14 primers geraram polimorfismo de banda, no entanto, as populações apresentaram baixo número de locos polimórficos (27 em BSR, 18 em C, 7 em SJC, 9 em D, 0 em B e P) sendo o maior conteúdo de informação polimórfica foi encontrado nos municípios de BSR (9 grupos), C (22 grupos), São João do Cariri (7 grupos) e D (6 grupos). Formou-se 34 grupos na análise interpopulacional. As matrizes formadas apresentaram altos índices de correlação cofenética $(0,95$ a 0,98$)$, baixo estresse $(12,9$ a $17,45 \%)$ e distorção $(3,05 \%)$. Portanto, há variabilidade genética entre e dentro de populações de feijão-bravo.

Palavras-chave: Biotecnologia. Caatinga. Marcador molecular. Conservação de espécies.

\footnotetext{
*Corresponding author

${ }^{1}$ Received for publication in $06 / 14 / 2017$; accepted in 04/19/2018.

Paper extracted from the doctoral thesis of the first author.

${ }^{2}$ Postgraduate Agronomy Program. Universidade Federal da Paraíba, Areia, PB, Brazil; netobiologia2@gmail.com - ORCID: 0000-00025903-1624.

${ }^{3}$ Department of Biological Sciences, Universidade Federal da Paraíba, Areia, PB, Brazil; mailson@cca.ufpb.br - ORCID: 0000-0003-30966992.

${ }^{4}$ Department of Social and Fundamental Sciences, Universidade Federal da Paraíba, Areia, PB, Brazil; elizanilda@cca.ufpb.br - ORCID 0000-0001-7376-7569.

${ }^{5}$ Post-Doctorate in Ruminant Production, Universidade Estadual do Sudoeste da Bahia, Itapetinga, BA, Brazil; anazte@hotmail.com ORCID: 0000-0002-4544-0339.
} 


\section{INTRODUCTION}

Genetic diversity refers to variability in the distribution of genes and alleles both among and within populations, provenances, or other types of groupings. Knowledge of genetic diversity is important in establishing strategies for the collection, conservation, and germplasm management of any species (OLIVEIRA; SILVA, 2008). Several factors can affect the distribution of genetic diversity, such as population size, reproductive system, mutation, migration, and natural selection (SOUSA, 2016).

According to Gaiotto, Grattapaglia and Venkovsky (2003), plant population dynamics can significantly affect evolutionary factors such as selection and genetic drift, which consequently have important impacts on their population genetic structure. However, the relative magnitude of the effects of drift and selection will depend on the organism's reproductive capacity and gene flow. Moreover, information on genetic diversity is important both for the study of flora and the elaboration of strategies for the conservation and rational use of genetic resources (KAMADA et al., 2009).

Previous studies, such as Kamada et al. (2009), have indicated that for characterizing genetic diversity there are basically four types of markers that are used: morphological, biochemical, cytological, and molecular. DNA molecular markers are genomic sequences that allow studies to characterize the genetic basis of a phenotype, which can then be used as a tool in studies of genetic diversity among individuals, as well as among and within populations or related species (SOUZA et al., 2008).

Among molecular markers, Random Amplified Polymorphic DNA (RAPD) markers have many considerable advantages in relation to other molecular techniques, including: simplicity, high speed, low cost, minimum quantities of DNA required for analysis (KUMAR; GURUSUBRAMANIAN, 2011), and the ability to use them to study species for which no genetic information is available and/or for isoenzymatic loci with little or no polymorphism (LACERDA et al., 2002).

Although RAPD molecular markers have been used in some studies of the genetics of species in the Caatinga biome (SILVEIRA et al., 2009; BELTRÃO et al., 2007; SANTOS et al., 2012; PINTO et al., 2011; SANTOS et al., 2013), relatively few genetic diversity studies using these molecular markers in Caatinga species have been conducted overall. Given this, it is necessary that research in this field be broadened and deepened, so that biome areas needing preservation can be identified and potential genotypes for use (or not) by the human population can be chosen, among other purposes.

Among Caatinga species, the brave bean (Capparis flexuosa L.) of the Capparaceae family has been used as forage (ALMEIDA NETO et al., 2011; LOPES et al., 2009; GONÇALVES et al., 2008; COSTA et al., 2011; DAMASCENO; SOUTO; SOUTO, 2010), for example for feeding animals in the semi-arid, medicinal region (ALMEIDA NETO et al., 2009), among others. However, despite its importance there is no information in the literature about the genetic variability of this species.

Therefore, the objective of the present study was to quantify the genetic diversity among and within populations of brave bean (Capparis flexuosa L.) using RAPD markers.

\section{MATERIAL AND METHODS}

\section{Characterization of the study area}

The present study was carried out at the locations of 6 natural brave bean (Capparis flexuosa L.) populations, located in different municipalities of Paraíba state, Brazil: Barra de Santa Rosa (BSR), Cuité (C), São João do Cariri (SJC), Damião (D), Baraúna (B), and Picuí (P) (Figure 1).

\section{Experimental materials}

Young leaves of plants from 30 accessions were collected in each municipality. The plant material collected was then taken to the Plant Biotechnology Federal University of Paraíba Sciences Center Agricultural Laboratory, located in Areia city, Paraíba, Brazil, to study its genetic diversity.

\section{DNA extraction}

DNA extraction followed the methods of Ferreira and Grattapaglia (1998), with some modifications. About $200 \mathrm{mg}$ of plant tissue was macerated in liquid nitrogen to form a thin powder. Then, $700 \mu \mathrm{L}$ of extraction buffer $(2 \%$ CTAB, $1.4 \mathrm{M}$ $\mathrm{NaCl}, 20 \mathrm{mM}$ EDTA, Tris- $\mathrm{HCl}(\mathrm{pH}=8.0)$, distilled water, and $2 \mu \mathrm{L} \beta$-mercaptoethanol) was added to this powder and shaken manually for $1 \mathrm{~min}$. This material was placed in a water bath at $65^{\circ} \mathrm{C}$ for 30 min, homogenizing it manually every $10 \mathrm{~min}$, and then it was cooled to room temperature. 


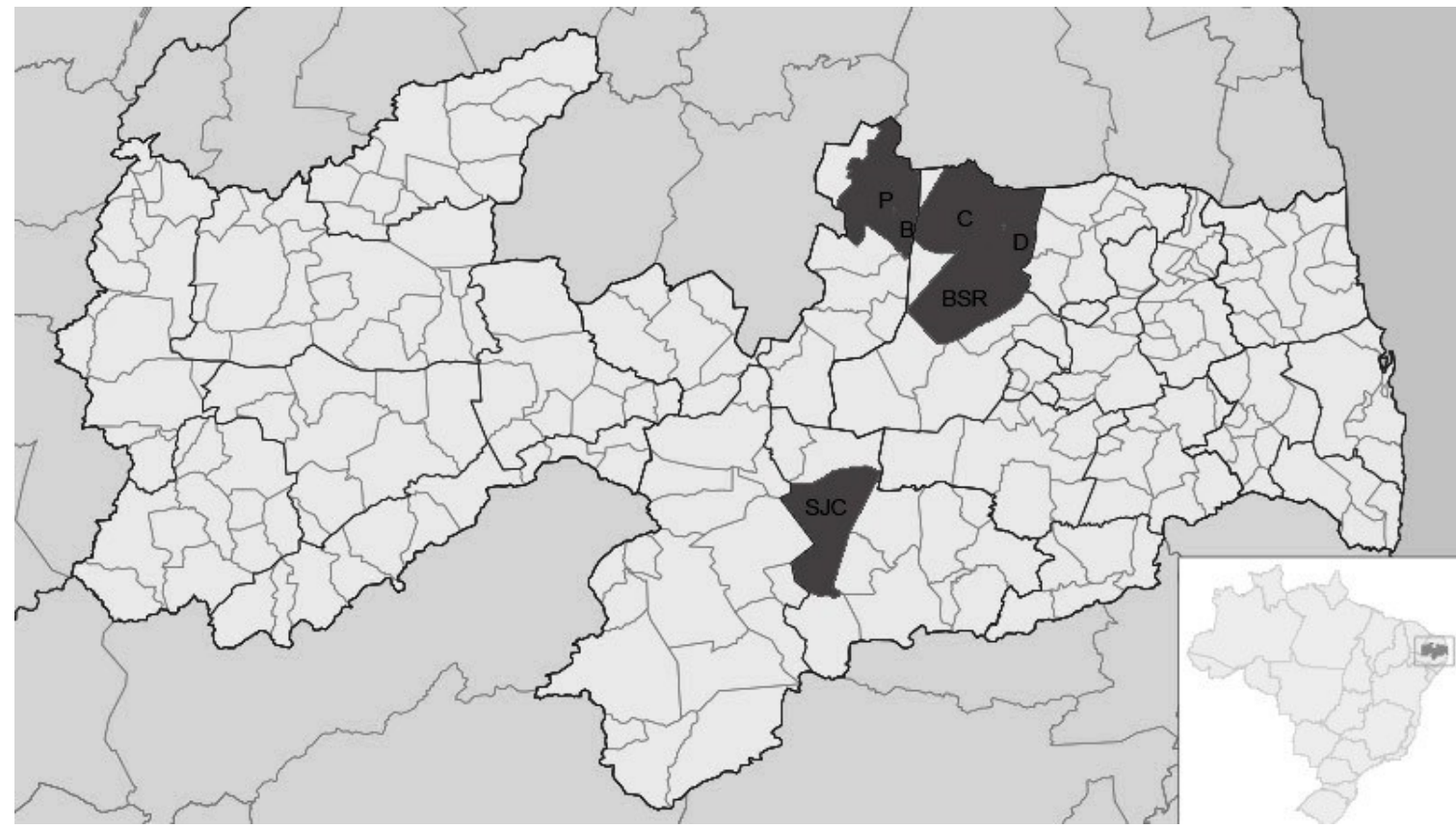

Figure 1. The brave bean (Capparis flexuosa L.) populations sampled in this study, located in different municipalities of Paraíba state, Brazil. BSR: Barra de Santa Rosa. C: Cuité. SJC: São João do Cariri. D: Damião. B: Barauna. P: Picuí. Map adapted from Wikipédia (2013).

$600 \mu \mathrm{L}$ of pre-frozen CIA [chloroformisoamyl alcohol (24: $1 / \mathrm{v}: \mathrm{v})]$ was added by hand and homogenized by carefully inverting the mixture for about $1 \mathrm{~min}$. Subsequently, the tubes were centrifuged at 13,400 rpm for $10 \mathrm{~min}$. Then, $600 \mu \mathrm{L}$ of the supernatant was transferred to a new microtube, to which $500 \mu \mathrm{L}$ of CIA was subsequently added and homogenized again by inversion, and then the mixture was again centrifuged at 13,400 rpm for $5 \mathrm{~min}$. After this, the upper phase (approximately $400 \mu \mathrm{L}$ ) was transferred to a new microtube with $40 \mu \mathrm{L}$ of wash buffer $(10 \mathrm{~g}$ CTAB, $8.12 \mathrm{~g}$ of $1.4 \mathrm{M} \mathrm{NaCl}$, and distilled water added to $100 \mathrm{~mL}$ ) added and homogenized by inversion for $5 \mathrm{~min}$.

After homogenization, $500 \mu \mathrm{L}$ of CIA was added and centrifuged again at 13,400 rpm for $5 \mathrm{~min}$. Then, $280 \mu \mathrm{L}$ of the supernatant was transferred to a new microtube and $185 \mu \mathrm{L}$ ice-cold isopropanol was added by mixing gently. The pellet that formed was then centrifuged at 13,400 rpm for $5 \mathrm{~min}$.

The supernatant was discarded, and $1 \mathrm{~mL}$ of $70 \%$ ethanol was added, after which the microtubes were left on the stand for $10 \mathrm{~min}$. After that, all remaining supernatant was discarded. This operation was repeated twice. Then, for $2 \mathrm{~min} 1 \mathrm{~mL}$ of absolute ethanol was added and centrifuged at 13,400 rpm. The supernatant was discarded, and the pellet was left on the table and allowed to dry completely. The pellet was then resuspended in 50 $\mu \mathrm{L}$ of buffer TE $[10 \mathrm{~mL}$ of $1 \mathrm{M}$ Tris- $\mathrm{HCl}(\mathrm{pH}=$ 8.0 ,), $2 \mathrm{~mL}$ of $1 \mathrm{mM}$ EDTA, and distilled water added to $1000 \mathrm{~mL}$. The extracted DNA was stored at $-20^{\circ} \mathrm{C}$ until use in the RAPD reactions.

\section{Polymerase Chain Reaction (PCR)}

A final volume of $25 \mu \mathrm{L}$ was used for DNA amplification, with $23 \mu \mathrm{L}$ Master Mix $(2.5 \mu \mathrm{L} 10 \mathrm{X}$ Buffer $+1.5 \mu \mathrm{L} \mathrm{MgCl} 2+0.5 \mu \mathrm{L} \mathrm{dNTP}+2.5 \mu \mathrm{L}$ primer $+0.2 \mu \mathrm{L}$ Taq DNA polymerase $+15.8 \mu \mathrm{L}$ $\mathrm{H}_{2} \mathrm{O}$ DDA) and $2 \mu \mathrm{L}$ of genomic DNA from the sample at a concentration of $5 \mathrm{ng} \mu \mathrm{L}^{-1}$. $18 \mathrm{RAPD}$ primers (Table 1) of the Operon Co series (A and B) (Operon Technologies, Alameda, CA, USA) were used.

The amplification reaction was carried out on a Techne TC-PLUS thermocycler (Bibby Scientific, Ltd.) as follows: one cycle at $94^{\circ} \mathrm{C}$ for $5 \mathrm{~min}$, followed by 30 cycles of $94^{\circ} \mathrm{C}$ for $1 \mathrm{~min}, 36^{\circ} \mathrm{C}$ for 1 min, and $72^{\circ} \mathrm{C}$ for $2 \mathrm{~min}$, and a final extension cycle at $72^{\circ} \mathrm{C}$ for $5 \mathrm{~min}$. 
Table 1. Identification codes and sequences of RAPD primers used for genetic diversity analyses of brave bean (Capparis flexuosa L.) populations in this study.

\begin{tabular}{ccc}
\hline Number & Primer & Sequence $\left(5^{\prime} \rightarrow 3^{\prime}\right)$ \\
\hline 1 & OPA -01 & CAGGCCCTTC \\
2 & OPA -02 & TGCCGAGCTG \\
3 & OPA -03 & AGTCAGCCAC \\
4 & OPA -04 & AATCGGGCTG \\
5 & OPA -05 & AGGGGTCTTG \\
6 & OPA -06 & GGTCCCTGAC \\
7 & OPA -08 & GTGACGTAGG \\
8 & OPA -09 & GGGTAACGCC \\
9 & OPA -12 & TCGGCGATAG \\
10 & OPA -13 & CAGCACCCAC \\
11 & OPA -14 & TCTGTGCTGG \\
12 & OPA -16 & AGCCAGCGAA \\
13 & OPA -17 & GACCGCTTGT \\
14 & OPA -18 & AGGTGACCGT \\
15 & OPB -01 & GTTTCGCTCC \\
16 & OPB -02 & TGATCCCTGG \\
17 & OPB -03 & CATCCCCCTG \\
18 & OPB -04 & GGACTGGAGT \\
\hline
\end{tabular}

\section{Gel electrophoresis}

An electrophoresis tub (120 mm x $120 \mathrm{~mm})$ containing $72 \mathrm{~mL}$ of $1.5 \%$ agarose gel in TAE $1 \mathrm{X}$ and $1.2 \mu \mathrm{L}$ of buffer and $1.2 \mu \mathrm{L}$ of ethidium bromide was used. The samples were prepared and run by combining $10 \mu \mathrm{L}$ of the resulting PCR sample mixed with $2 \mu \mathrm{L}$ of sample buffer $(4.0 \mathrm{~g}$ glucose, $0.025 \mathrm{~g}$ bromophenol blue, $0.025 \mathrm{~g}$ xylene cyanol, and 10 $\mathrm{mL}$ distilled water).

As a molecular weight standard, $4 \mu \mathrm{L}$ of $1 \mathrm{~Kb}$ molecular weight marker was used. Electrophoresis was run using a $70 \mathrm{~V}$ current. The gels were photographed in a transilluminator with an Easy Doc 200 UV light.

\section{Data analyses}

A dissimilarity matrix was obtained by calculating the values of the Complement (1-C) Jaccard (1901) Similarity coefficient among samples, and then grouping them using the Unweighted Pair Group Method with Arithmetic Mean (UPGMA) hierarchical clustering method. For the interpopulation analysis, accessions for which sequences could not be amplified were excluded. A polymorphic locus was considered one for which the frequency of the most common allele was less than 0.95 (HARTL; CLARK, 2010). The cutoff point for grouping in the dendrogram was determined following the Mojema (1977) criterion.

Values of the Cophenetic Correlation Coefficient (CCC), Distortion, and Stress were also calculated. All statistical analyses were done in the computer program Genes (CRUZ, 2006).

\section{RESULTS AND DISCUSSION}

The number of loci evaluated in individuals among and within the brave bean (Capparis flexuosa L.) populations are showed in Table 2 .

Table 2. Numbers of amplified DNA loci determined to be monomorphic and polymorphic among and within brave bean (Capparis flexuosa L.) populations in 6 Paraíba state municipalities.

\begin{tabular}{ccccc}
\hline Population & Amplified loci & Monomorphic loci & Polymorphic loci & \% polymorphism \\
\hline BSR & 73 & 46 & 27 & 37 \\
C & 63 & 45 & 18 & 28.6 \\
SJC & 47 & 40 & 7 & 15 \\
D & 30 & 21 & 9 & 30 \\
B & 11 & 11 & 0 & 0 \\
P & 2 & 2 & 0 & 0 \\
Interpopulation & 181 & 159 & 22 & 12.1 \\
\hline
\end{tabular}

BSR: Barra de Santa Rosa. C: Cuité. SJC: São João do Cariri. D: Damião. B: Baraúna. P: Picuí. 
In all analyses (both among and within populations) the number of monomorphic loci was higher than the number of polymorphic loci. In general, because it is an autogamous species, brave bean presents low genetic variability among individuals belonging to the same population. Although the $\mathrm{B}$ and $\mathrm{P}$ populations did not present any polymorphism, the others presented percentages of polymorphism ranging from $15 \%$ to $37 \%$ (Table 2 ). In other words, these populations all presented low genetic variability, which may have been due to the limited number of primers used in this study. However, it can still be said that there was genetic variability among and within the brave bean populations examined, although it was very low overall.

In the case of the Baraúna and Picuí municipalities, the extremely low diversity observed may have been caused by deforestation for soil use (e.g., agriculture, raising cattle, and construction of homes, among others) in these municipalities.

A founder effect from population formation, which is the effect of the sample of some few individuals being taken from a larger population to form new populations (BORÉM; MIRANDA, 2013), could also have been involved in some of our results due to the nature of propagation by brave bean. Hamrick and Godt (1990) observed that crossfertilizing (allogamous) species retain most of their genetic variation within their populations, while in self-propagating species variability is small within populations and is mainly maintained among populations. Regarding brave bean populations, in this study there was greater genetic variability among than within populations. This may have been due to the limited number of molecular markers used in this work, which did not find polymorphism in municipalities B and P. Maia (2010) explained that allogamous populations transmit only some of their alleles to the following generations, whereas autogamous populations transfer their complete sets of genes by fixing them in advanced generations through successive natural self-fertilization. Regarding to the brave bean conservation area, the Barra de Santa Rosa municipality population was the one with the highest number of polymorphic loci, which was 27 in total.

The populations that presented the greatest amount of polymorphism were those in the Barra de Santa Rosa, Cuité, São João do Cariri, and Damião municipalities, so this may indicate that these should be used as conservation areas for brave bean diversity. Their importance for conservation shows the potential impacts of the use of brave beans from these population (such as for forage, medicinal purposes, and recovery of salinized areas, among others), as well as their relation to other factors, for example the occurrence of rains. Further, their importance demonstrates that they could be sources for germplasm conservation in the face of damage caused by deforestation to brave bean populations, and perhaps for other Caatinga species as well.

For the accessions sampled from the Baraúna and Picuí municipalities, no polymorphism was found with the 18 RAPD primers used in this study. This may be an indication of the occurrence of genetic erosion in these populations, i.e., the loss of genetic variability (BORÉM; MIRANDA, 2013), which can occur due to export of propagules, such as seeds, from one population to another and, thus, the formation of a new population(s) rather than replenishing their source population.

With the exception of the Baraúna and Picuí populations, it was possible to verify the ability of the RAPD markers to efficiently detect polymorphism among individuals of a species that reproduces mainly by self-fertilization. Heun, Murphy and Phillips (1994) pointed out that probably the most important contribution made by DNA-based markers like RAPDs is the possibility to determine more precisely the relationships among individuals.

Kamada et al. (2009) studied the genetic diversity of four Pfaffia glomerata populations and demonstrated the effectiveness of the RAPD technique to obtain polymorphic fragments to use to estimate the genetic distance between accessions. Similar results were also found in this study, as it was possible to obtain polymorphic fragments with which to group individuals using the UPGMA method.

Silveira et al. (2009) also used the RAPD technique in studies of caroá (Neoglaziovia variegata) populations, and concluded that there was genetic variability among and within the caroá populations, which can thus be exploited commercially and used for conservation. Genetic variability was also detected among and within brave bean populations in the present study. Although relatively few studies about genetic diversity in Caatinga species have been carried out, RAPD markers have been used in other studies, such as those of umburana (Amburana cearensis), aroeira (Myracrodruon urundeuva), baraúna (Schinopsis brasiliensis) (SANTOS et al., 2007), catingueiraverdadeira (Poincianella pyramidalis), catinga-deporco (Poincianella bracteosa) (MENDES et al., 2014), juazeiro (Ziziphus joazeiro) (GOIS et al., 2014), and velame (Croton heliotropiifolius) (ROCHA et al., 2016). As for the low-diversity Baraúna and Picuí populations, it is necessary to use a larger number of RAPD markers in a future study to access more loci and more thoroughly study the genetic variability of these populations.

Based on the Mojema (1977) criterion, a cut was made at a dissimilarity value of 0.036 to form 10 groups within the Barra de Santa Rosa municipality (Figure 2). The first group consisted of 21 accessions, and the other nine groups were composed of single, isolated accessions each. 
The population located in the Cuité municipality (Figure 2) was cut at a value of 0.0208 , resulting in the formation of 21 groups. One group contained 9 accessions, one group contained 2 accessions, and the other groups contained one accession each. The RAPD markers used were thus able to identify 21 groups within a group of 30 accessions.

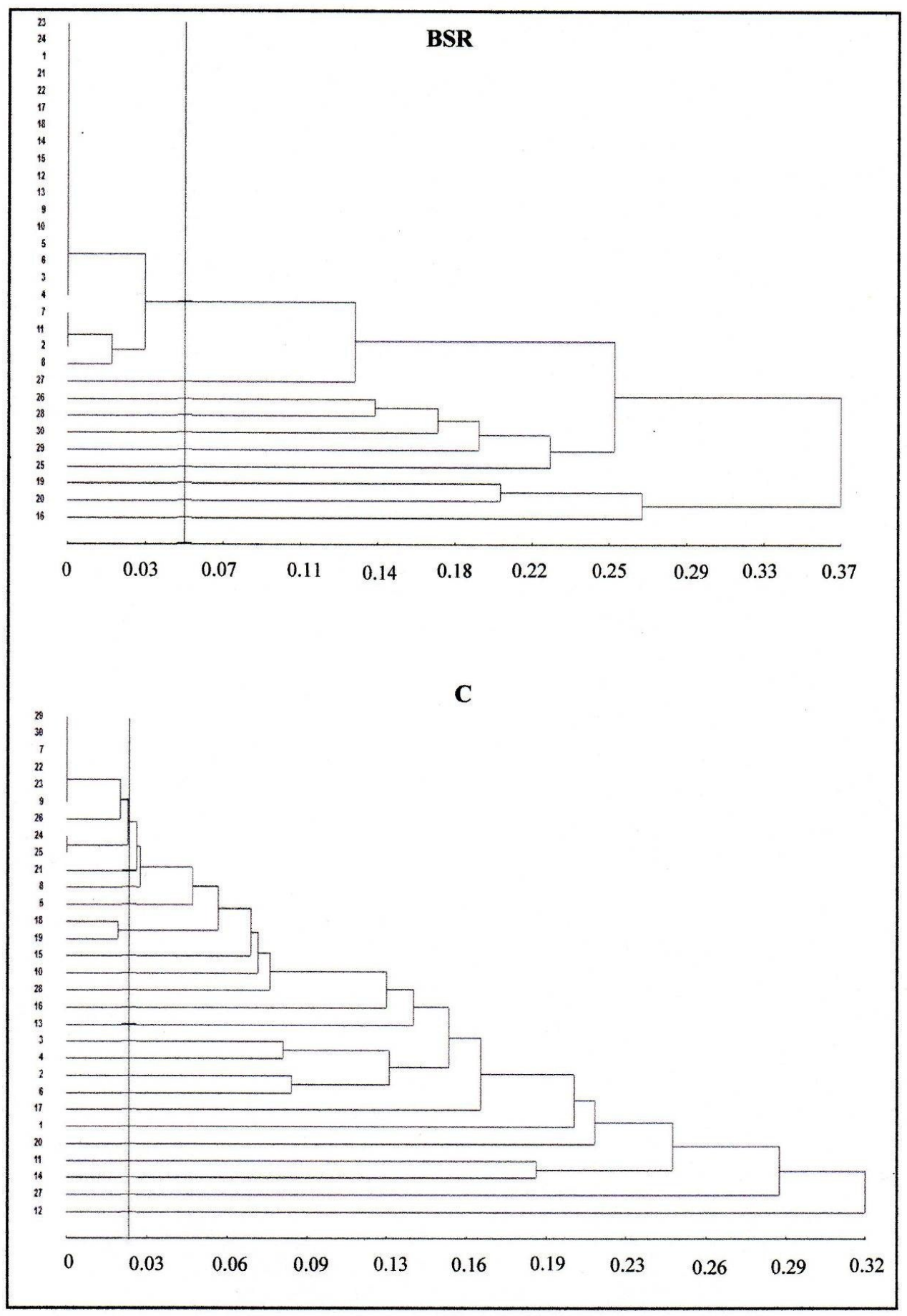

Figure 2. Dendrograms formed from analysis of RAPD markers in two brave bean (Capparis flexuosa L.) populations by using the UPGMA method. BSR: Barra de Santa Rosa. C: Cuité. 
Cuts made in the São João do Cariri and Damião municipalities' populations (Figure 3) were as follows: at a dissimilarity value of 0.0493 seven groups were formed (the first group with 14 accessions, the second with 11 accessions, and the others with one accession each) and at a value of 0.1667 six groups were formed (the first group consisted of 23 accessions, two groups were formed with 2 accessions each, and the others contained accession each), respectively.

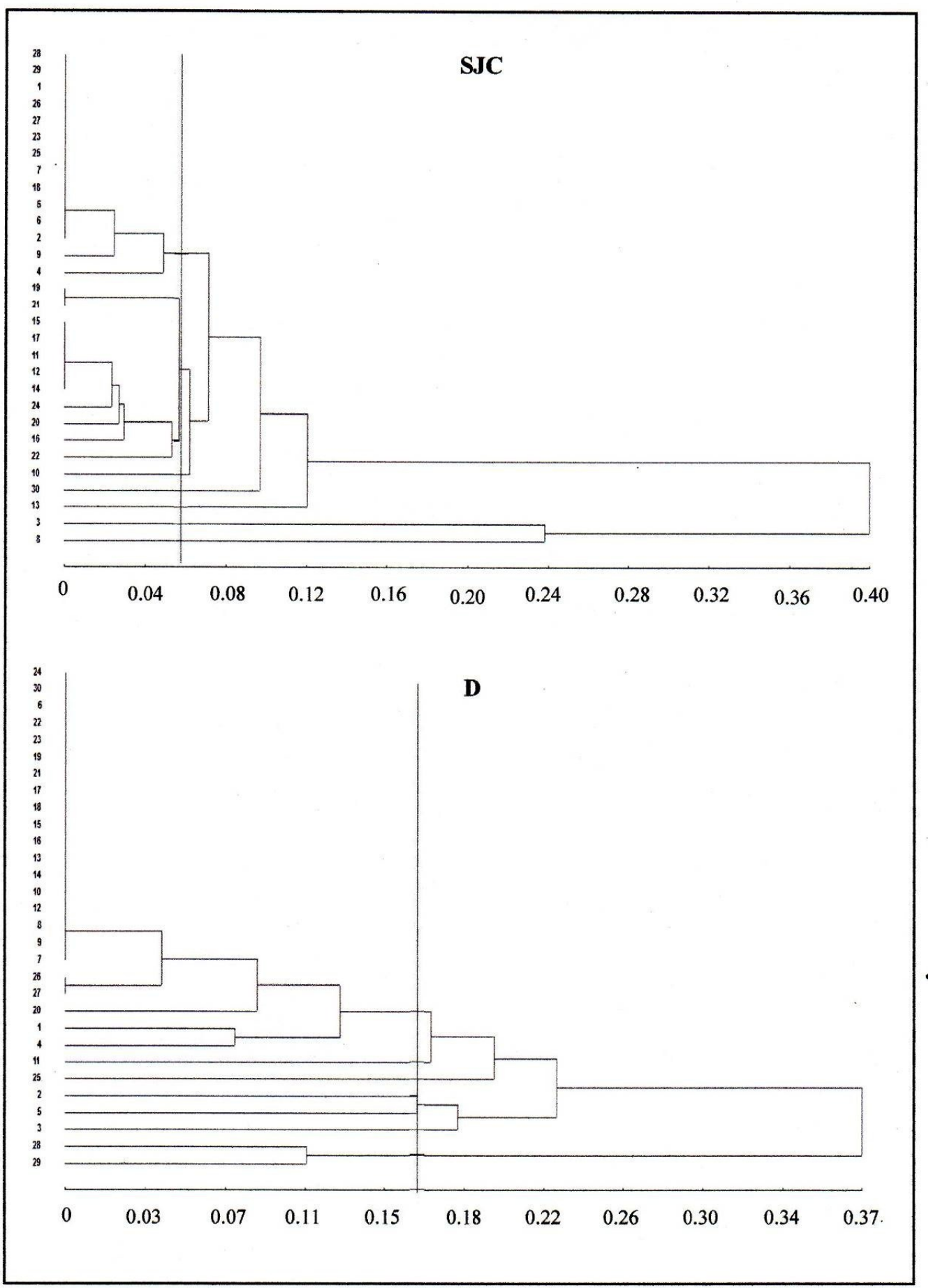

Figure 3. Dendrograms formed from analysis of RAPD markers in two brave bean (Capparis flexuosa L.) populations by using the UPGMA method. SJC: São João do Cariri. D: Damião. 
The Baraúna and Picuí populations formed only one group. This was due to the detection of no polymorphism among the accessions in these groups. A greater number of RAPD tags is required to assess loci that could provide evidence of polymorphism among the accessions from these municipalities.

As for the interpopulation analysis (Figure 4), the cut was made at a dissimilarity value of 0.0273 , forming 29 groups.

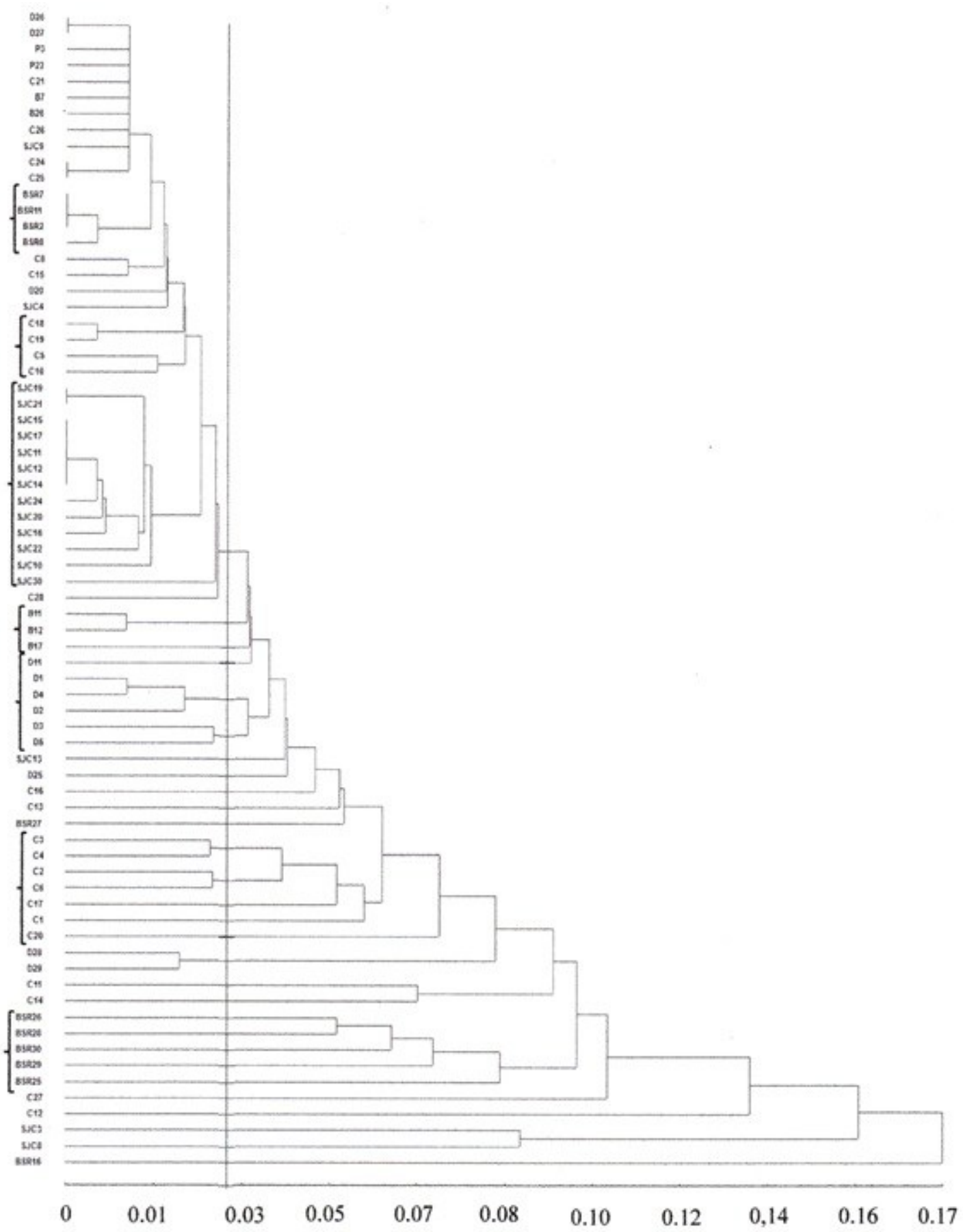

Figure 4. Genetic diversity among brave bean (Capparis flexuosa L.) populations from 6 municipalities in Paraíba state, Brazil, analyzed using the UPGMA method. 
The first group consisted of 37 accessions, another group contained 3 accessions, five groups contained 2 accessions each, and the other groups contained one accession each. The RAPD markers used were able to detect these 29 groups across all sampled populations. Although the accessions not amplified by the RAPD markers were removed from these analyses, the number of clusters formed would not have been altered if these accessions had been included in the Figure 4 dendrogram.

Some groups of accessions were identified that contained samples that came from the same population and were closer (i.e., more similar) to each other compared with others. Considering groups of at least 3 accessions, the following groups were identified: $\operatorname{BSR}(7,11,28)(25,26,28,30,30), \mathrm{C}$ $(5,10,18,19)(1,2,3,4,6,17,20)$, SJC $(10,11,12,14$, $15,16,17,19,20,21,22,24,30)$, and $\mathrm{B}(11,12,17)$. Therefore, São João do Cariri presented a larger municipality group, and was the most distant from the other areas. This shows, once again, that most of the genetic variability occurred among populations in this study. Table 3 shows the Cophenetic Correlation results, as well as Stress and Distortion values.

Table 3. Cophenetic Correlation Coefficient (CCC), Stress, and Distortion values from genetic diversity analyses using RAPD markers in brave bean (Capparis flexuosa L.) populations.

\begin{tabular}{|c|c|c|c|c|c|c|}
\hline Stat. & Pop. & BSR & $\mathrm{C}$ & SJC & $\mathrm{D}$ & IP \\
\hline $\mathrm{CCC}$ & & 0.98 & 0.96 & 0.98 & 0.98 & 0.95 \\
\hline Stress (\%) & & 14.44 & 14.9 & 12.9 & 15 & 17.45 \\
\hline Distortion (\%) & & 2.08 & 2.22 & 1.65 & 2.23 & 3.05 \\
\hline
\end{tabular}

Pop.: Population. Stat:: Statistic. IP: Interpopulation. BSR: Barra de Santa Rosa. C: Cuité. SJC: São João do Cariri. D: Damião. B: Baraúna. P: Picuí.

The Cophenetic Correlation Coefficients ranged from 0.95 to 0.98 , and therefore they were significant and high in value, which provides evidence of high cluster consistency. Stress varied from $12.9 \%$ to $17.45 \%$, so therefore according to Kruskal (1964) the adjustment between the phenetic and cofenética matrices is classified to be reasonable. The maximum distortion found was $3.05 \%$ in the Interpopulation comparison, which was considered low, and thus showed that there was a good fit between the genetic dissimilarity matrix and the graphical representation in the dendrogram. Therefore, the statistical methods used were effective at detecting the dissimilarity between the studied brave bean populations and accessions.

\section{CONCLUSIONS}

There is genetic variability among and within brave bean (Capparis flexuosa L.) populations.

The brave bean has low genetic variability overall.

The indicated actions areas for brave bean conservation are Barra de Santa Rosa, Cuité, São João do Cariri, and Damião.

With the exception of the Baraúna and Picuí municipalities, the primers used are effective for identifying polymorphism in brave bean genes. There is a need for a greater number of RAPD primers for use in the Baraúna and Picuí municipalities.

The matrices that generated the dendrograms had high consistency and good adjustment indices between the genetic dissimilarity matrix and the graphical dendrogram representation.

\section{ACKNOWLEDGMENTS}

The present work is part of the thesis of the first author, who had financial support from the Higher Education Personnel (CAPES) Coordination Improvement.

\section{REFERENCES}

ALMEIDA NETO, J. X. et al. Composição florística, estrutura e análise populacional do feijão-bravo (Capparis flexuosa L.) no semiárido paraibano, Brasil. Revista Caatinga, v. 22, n. 4, p. 187-194, 2009.

ALMEIDA NETO, J. X. et al. Crescimento e bromatologia do feijão-bravo (Capparis flexuosa L.) em área de Caatinga no Curimataú paraibano, Brasil. Revista Ciência Agronômica, v. 42, n. 2, p. 488 494, 2011.

BELTRÃO, F. A. S. et al. Avaliação da diversidade genética através de RAPD de acessos de maniçoba (Manihot pseudoglaziovii Pax e Hoffm.) e de duas espécies afins de interesse forrageiro. Revista Caatinga, v. 20, n. 2, p. 118-126, 2007.

BORÉM, A.; MIRANDA, G. V. Melhoramento de Plantas. 6 ed. Viçosa, MG: UFV, 2013, 523 p.

COSTA, M. R. G. F. et al. Utilização do feno de forrageiras lenhosas nativas do Nordeste brasileiro na alimentação de ovinos e caprinos. Pubvet, v. 5, n. 7, p. 1-17, 2011. 
CRUZ, C. D. Programa genes: estatística experimental e matrizes. 1 ed. Viçosa, MG: UFV, 2006, 285 p.

DAMASCENO, M. M.; SOUTO, J. S.; SOUTO, P. C. Etnoconhecimento de espécies forrageiras no semi-árido da Paraíba, Brasil. Engenharia Ambiental, v. 7, n. 3, p. 219 -228, 2010.

FERREIRA, M. E.; GRATTAPAGLIA, D. Introdução ao uso de marcadores moleculares em análise genética. 3 ed. Brasília, DF: Embrapa Cenargen, 1998. 220 p.

GAIOTTO, F. A.; GRATTAPAGLIA, D.; VENKOVSKY, R. Genetic structure, mating system and long distance gene flow in heart of palm (Euterpe edulis Mart.). Journal of Heredity, v. 94, n. 5, p. 399-406, 2003.

GOIS, I. B. et al. Variabilidade genética em populações naturais de Ziziphus joazeiro Mart., por meio de marcadores moleculares RAPD. Revista Árvore, v. 38, n. 4, p. 621-630, 2014.

GONÇALVES, G. S. et al. Desempenho de cordeiros alimentados com dietas contendo sal forrageiro de espécies vegetais xerófitas. Revista Brasileira de Zootecnia, v. 37, n. 12, p. 2185-2190, 2008.

HAMRICK, J. L.; GODT, M. J. W. Allozyme diversity in plant species. In: BROWN, A. H. D. et al. (Eds). Plant population genetics, breeding and genetic resources. Sunderland, MA: Sinauer Associates, 1990. 43-63 p.

HARTL, D. L.; CLARK, A. G. Principles of population genetics. 4 ed. Porto Alegre, RS: Artmed, 2010, 660 p.

HEUN, M.; MURPHY, J. P.; PHILLIPS, T. D. A comparison of RAPD and isozyme analyses for determining the genetic relationships among Avena sterilis L. accessions. Theoretical and Applied Genetics, v. 87, n. 6, p. 689-696, 1994.

JACCARD, P. Etude comparative de la distribution florare dans une portion des Alpes et du Jura. Bulletin Société Vaudoise dês Sciences Naturelles, Lausanne, p. 547-579, 1901.

KAMADA, T. et al. Diversidade genética de populações naturais de Pfaffia glomerata (Spreng.) Pedersen estimada por marcadores RAPD. Acta Scientiarum. Agronomy, v. 31, n. 3, p. 403-409, 2009.

KRUSKAL, J. B. Multidimensional scaling by optimizing goodness of fit to a non-metric hypothesis. Psychometrika, v. 29, n. 1, p. 1-27, 1964.

KUMAR， N. S.; GURUSUBRAMANIAN， G. Random amplified polymorphic DNA (RAPD) markers and its applications. Science Vision, v. 11, n. 3, p. 116-124, 2011.

LACERDA, D. R. et al. A técnica de RAPD: uma ferramenta molecular em estudos de conservação de plantas. Lundiana, v. 3, n. 2, p. 87-92, 2002.

LOPES, W. B. et al. Caracterização de uma população de plantas de feijão bravo (Capparis flexuosa L.) no cariri paraibano. Revista Caatinga, v. 22, n. 2, p. 125-131, 2009.

MAIA, M. C. C. Sistema reprodutivo de populações alógamas e autógamas: modelo básico e equilíbrio. Revista Agroambiente, v. 4, n. 1, p. 53-54, 2010.

MENDES, R. F. M. et al. RAPD analysis of the genetic diversity among accessions of Fabaceous forages (Poincianella spp) from the Caatinga. Genetics and Molecular Research, v. 13, n. 3, p. 5832-5839, 2014.

MOJEMA, R. Hierarquical grouping methods and stopping rules: an evaluation. The Computer Journal, v. 20, n. 4, p. 359-363, 1977.

OLIVEIRA, M. S. P.; SILVA, K. J. D. Diferenciação genética entre procedências de açaizeiro por marcadores RAPD e SSR. Revista Brasileira de Fruticultura, v. 30, n. 2, p. 438-443, 2008.

PINTO, J. A. O. et al. Caracterização molecular (RAPD) de acessos de alecrim-detabuleiro (Lippia gracilis Schauer). Scientia Plena, v. 7, n. 7, p. 1-6, 2011 .

ROCHA, T. O. et al. Estimate of genetic diversity in cassutinga (Croton heliotropiifolius) based on molecular markers. African Journal of Biotechnology, v. 15, n. 13, p. 518-523, 2016.

SANTOS, C. A. F. et al. Variabilidade genética, com base em marcadores RAPD, de três espécies arbóreas ameaçadas de extinção no semiárido brasileiro. Scientia Forestalis, v. 74, s/n, p. 37-44, 2007.

SANTOS, J. S. et al. Genetic Diversity assessment of Poincianella pyramidalis (Tul.) L.P. Queiroz accessions using RAPD markers. Scientia plena, v. 8, n. 3, p. 1-8, 2012.

SANTOS, M. F. et al. Determination of the genetic diversity among accessions of Senna spectabilis (canafístula) by using RAPD markers. Genetics and Molecular Research, v. 12, n. 4, p. 6149-6155, 
2013.

SILVEIRA, D. G. et al. Genetic variability estimated among caroá populations through RAPD markers. Pesquisa Agropecuária Brasileira, v. 44, n. 3, p. 283-290, 2009.

SOUSA, N. R. Processos Genéticos-Evolutivos e os Recursos Fitogenéticos. Disponível em: <https:// www.inpa.gov.br/cpca/charles/pdf/

NSousa_Cap1.pdf $>$. Acesso em: 20 jun. 2016.

SOUZA, G. A. et al. Diversidade genética estimada com marcadores ISSR em populações brasileiras de Zabrotes subfasciatus. Pesquisa Agropecuária Brasileira, v. 43, n. 7, p. 843-849, 2008.

WIKIPÉDIA. Lista de Municípios da Paraíba. Disponível em: <https://pt.wikipedia.org/wiki/ Lista_de_munic\%C3\%ADpios_da_Para $\%$ C3\% $\mathrm{ADb} \overline{\mathrm{a}}>$. Acesso em: 27 de jun. $20 \overline{13}$. 